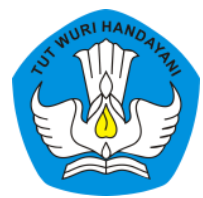

Page: 759-778

\title{
Pengembangan Model Pembelajaran Ecoprint untuk Meningkatakan Keterampilan Abad 21 di Sekolah Dasar
}

\section{Slamet Widiantoro}

Sekolah Dasar Negeri Petinggen Kota Yogyakarta

Contributor Email: slamet.widiantoro95@yahoo.co.id

Article Url: http://ojsdikdas.kemdikbud.go.id/index.php/didaktika/article/view/142

\begin{abstract}
The purpose of this research is to develop project-based learning media (Project Based Learning) to improve communication skills, collaboration, critical thinking, and creativity of 4 th grade elementary school students. The method used is ADDIE (Analysis, Design, Development for Production, Implementation and Evaluation). Data collection is done by questionnaire, observation and performance tests. Descriptive qualitative analysis techniques. This research produces ecoprint media which is used for project-based learning. The results of the implementation of the ecoprint media can enhance creativity, communication, collaboration, and critical thinking.
\end{abstract}

Keywords: Project Based Learning; Ecoprint; Skills 4C

\begin{abstract}
Abstrak
Tujuan penelitian ini yaitu mengembangkan media pembelajaran berbasis projek (Project Based Learning) untuk meningkatan keterampilan komunikasi, kolaborasi, berpikir kritis, dan kreatifitas siswa kelas 4 SD. Metode yang digunakan ADDIE (Analysis, Design, Development for Production, Implementation and Evaluation). Pengumpulan data dilakukan dengan angket, observasi dan tes performa. Teknik analisis secara diskriptif kualitatif. Penelitian ini menghasilkan media ecoprint yang dianfaatkan untuk pembelajaran berbasis projek. Hasil implementasi media ecoprint dapat meningkatkan kreatifitas, komunikasi, kolaborasi, dan berpikir kritis.
\end{abstract}

Keywords: pembelajaran berbasis projek; Ecoprint; Ketrampian $4 \mathrm{C}$ 


\section{A. Pendahuluan}

Guru dalam pembelajaran abad 21 dituntut untuk menyesuaikan pembelajaran yang sesuai dengan tuntutan pembelajaran tersebut. Salah satu model pembelajaran yang sesuai dengan pembelajaran abad 21 adalah Project Base Learning (PjBL) yang memberikan keunggulan dalam hal anak melakukan sebuah kegiatan proyek yang terstruktur sehingga mereka terbiasa untuk berkolaborasi, berkreasi dan berinovasi dengan mencipta. Model PjBL merupakan pembelajaran yang membuat peserta lebih aktif unttuk memecahkan permasalahan melalui beberapa tahapan dengan batasan waktu yang sudah ditentukan sebelumnya dan mengghasilkan produk, selanjutnya produk tersebut dipresentasikan kepada orang peserta didik lain atau masyarakat di lingkungan sekolah. Model ini menurut (Ariyana, Bestary, Zamroni, \& Pudjiastuti, 2018, p.40) PjBl memiliki kakarasteristik antara lain adalah : (1) penyelesaian proyek dilakukan secara mandiri oleh peserta didik; (2) peserta didik, guru, dan stakeholder proyek diajak aktif dan berperan; (3) peserta didik bertanggungjawab pada proyek; (4) ketrampilan berpikir kreatif dilatih dalam proyek; (5) pembelajaran yang cukup adaptif.

Pembelajaran berbasis proyek sangat mendukung pembelajaran kurikutlum 2013. Selain itu dengan model pembelajaran ini lebih bermakna dan memberikan pengalaman langsung kepada siswa dengan menghubungkan pembelajaran dengan dunia nyata. PjBL dalam pembelajaran ini yang digunakan adalah model dari (Ariyana, 2018: 40) yang sintaknya terdiri dari pengajuan pertanyaan, mendesain perencanaan produk, menyusun jadwal pembuatan proyek, memonitoring keaktifan siswa dan perkembangan proyek yang dihasilkan, menguji hasil, dan evaluasi pengalaman belajar.

Guru dalam melaksanakan pembelajaran tematik kadang memisahkan pembelajaran matematika, sains atau seni sehingga tujuan pembelajaran kurang sesuai. Selain itu pembelajaran di SD yang mendorong ketrampilan 4C juga masih belum maksimal.

Pembelajaran abad 21 mengarah pembelajaran yang menuntut siswa berpikir tingkat tinggi. Ketrampilan berpikir tingkat tinggi tersebut antara lain ketrmapilan 4C (comunucation, colaboration, critical thingking, creativty). Kompetensi 4C 
diuraikan (Nurhayati, 2018:9) sebagai berikut ini : Kecakapan berpikir kritis antar lain : 1) menggunakan penalaran dengan tepat; 2) memahami hubungan antara konsep antar pelajaran; 3) menentukan penilaian secara efektif; 4) dapat membuat kesimpulan dan mengujinya lewat analisis; 5) mampu membuat solusi degngan sendiri. Kecakapan kreativitas antara lain : 1) mampu berpikir produktif; 2) mampu mengembangkan gagasan baru secara lisan dan tulisan; 3) mengemukakan ide kreatif; 4) menggunakan konsep dalam situasi yang baru; 4) memiliki kemampaun mencipta. Kecakapan berkomunikasi antara lain : 1) mampu menyampaikan gagasan secara lesan dan tertulis; 2) bersikap terbuka terhadap perpesktif baru; 3) mampu berdapatsi dalam situasi baru. Kecakapan kolaborasi antara lain adalah : 1) memiliki kemampuan kerjasama dengan kelompok; 2) mampu beradapatsi dalam berbagi peran dan tangggung jawab; 3) menghormati perbedaan dan berempati; 4) mampu berkompromi dengan kelompok.

Dari uraian di atas, timbul beberapa masalah, media apa yang dapat dimanfaatkan untuk meningkatkan keterampilan 4C di kelas 4 SD? Apakah media tersebut mudah ditemukan di sekitar sekolah? Apakah media tersebut ramah anak dan mudah dimanfaatkan? Bagaimana cara mengembangkan media tersebut dengan biaya murah? Apakah guru mampu membuat media tersebut?

Dari berbagai masalah yang teridentifikasi tersebut, maka penelitian ini bertujuan untuk mengetahui media apakah yang dapat dimanfaatkan untuk meningkatkan kemampuan 4C bagi siswa SD kelas 4? Bagaimana cara mengembangkan media tersebut? Bagaimana implementasinya di kelas? Seberapa efektif media tersebut untuk meningakatkan kemampuan 4C siswa SD kelas 4 ?

\section{B. Metode}

Metode penelitian dan pengembangan ini menggunakan pedekatan ADDIE (Analysis, Design, Development for Production, Implementation and Evaluation). Model ADDIE untuk mendesain pembelajaran dan prosesnya dengan struktur kerja yang mudah dan dapat diaplikasikan dalam pengoperasiannya karena kerangkanya umum (Peterson, 2003). 
Tahapan pengembangan model ADDIE membentuk siklus yang terdiri dari 5 tahapan sebagai berikut: (1). analisis (Analysis), (2). desain (Design), (3). pengembangan (Development), (4). implementasi (Implementation), dan (5). evaluasi (Evaluation). (Sumber: http://padamu.net/desainpembelajaran-model-addie).

Pembelajaran melalui PjBL melalui ecoprint rancangan pengembangannya terlihat pada diagam gambar 2.1.

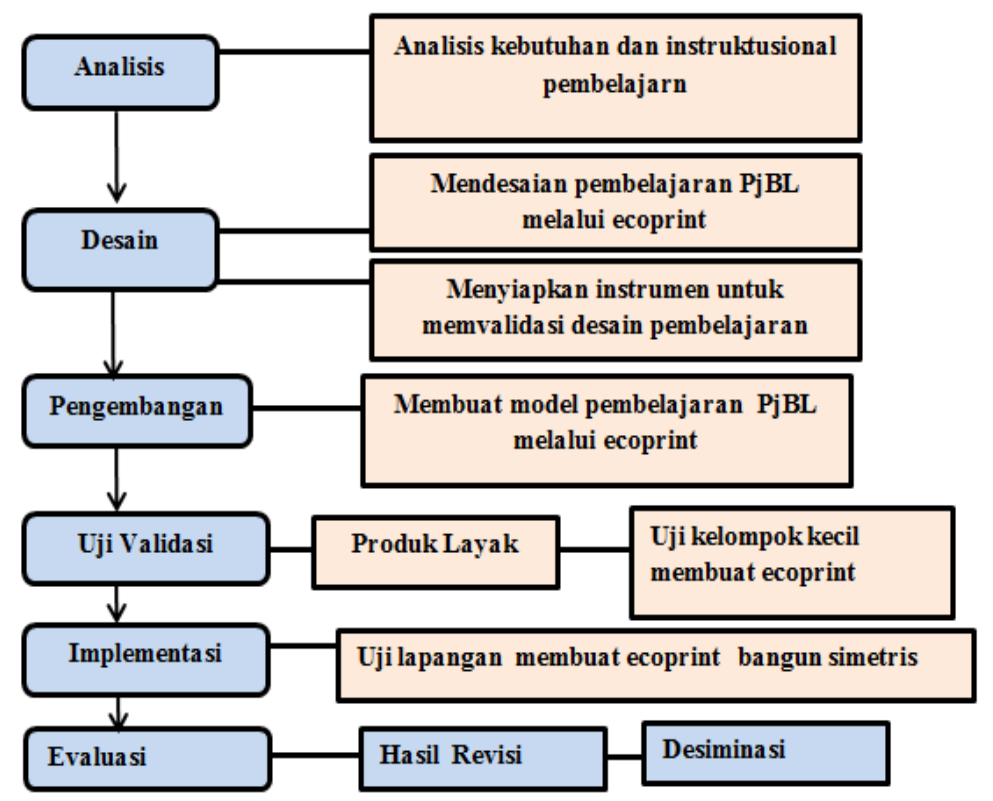

Gambar 2.1 Diagram Alur Rancangan Karya Inovasi Pembelajaran

Penelitian akan dilakukan di SDN Petinggen pada kelas 3 Yogyakarta pada semester 2 tahun ajaran 2018/2019. Pengumpulan data penelitian menggunakan instrumen lembar observasi, angket, tes posformen. Data yang terkumpul selanjutnya dianalisa sesuai secara kualitatif diskriptif.

Model yang dibuat divalidasi dengan menjawab 20 butir pertanyaan. Hasil yang didapat selanjutnya dijumlah sesuai dengan aspeknya dan disesuaikan dengan konversi skor ke nilai pada skala 5 dengan menentukan rerata ideal, simpangan baku ideal, dan skor actual. Hasilny seperti tabel konversi skor pada tabel 2.1 
Tabel 2. 1 Konversi Skor Model PjBL Skala Lima

\begin{tabular}{|l|c|l|}
\hline \multicolumn{1}{|c|}{ Interval Skor } & Nilai & \multicolumn{1}{c|}{ Kategori } \\
\hline$X>80,0$ & A & SangatBaik \\
\hline $66,7<X \leq 80,0$ & B & Baik \\
\hline $53,3<X \leq 66,7$ & C & Cukup \\
\hline $40,0<X \leq 53,3$ & D & Kurang \\
\hline$X \leq 40,0$ & E & Sangat kurang \\
\hline
\end{tabular}

Indikator yang digunakan untuk ketercapaian validasi model PjBL dikatakan layak minimal bernilai baik atau dikatakan layak untuk dapat diujicobakan dilapangan. Sedangkan untuk nilai ketrampilan $4 \mathrm{C}$ dengan ketuntasan nilai KKM 80.

\section{Hasil dan Pembahasan}

\section{Analisis Kebutuhan}

SDN Petinggen merupakan sekolah rintisan Adiwiyata sehingga guru ikut menciptakan pembelajaran yang mengarah kepada kearifan lokal dan berwawasan lingkungan. Ketika Penulis mengajar di kelas 4, berdasarkan analisis sebelum penelitian hanya ada $18 \%$ atau 5 orang peserta didik dari 28 anak yang berani menyampaikan pendapatnya, tingkat berpikir kritis masih kurang ketika diberi permasalahan yang dapat memecahkan ada $28 \%$ atau 8 orang anak. Tingkat kreativitas saat diberi tugas juga kurang, mereka lebih banyak mencontoh sekitar $86 \%$ atau sekitar 24 orang anak sehingga dapat dikatakan kurang kreatif. Begitu juga ketika diberi tugas, anak-anak yang pandai masih banyak mengerjakan secara mandiri, kurang membantu teman.

Berdasarkan itu penulis mengkaji KD pembelajaran yang dapat digunakan sebagai pembelajaran proyek yaitu kelas 4 tema 7 subtema teknologi sandang. Pembelajaran ini dapat bermakna dan mendukung kearifan lokal. Kearifan lokal yang ada di SDN Petinggen adalah mulok batik. Maka dari itu mengambil materi pembuatan karya dekoratif bangun simetris dengan ecoprint. Ecoprint adalah cara membuat motif pada sebuah media contohnya kain dengan teknik mencetak motif dengan bahan alam (Ningrum:2018). Berdasarkan pengalaman penulis mengikuti 
komunitas ecoprint, tumbuhan yang bisa di-ecoprint di nusantara sangat banyak, sehingga penerapan ecoprint ini bisa diterapkan di mana saja.

Melihat uraian di atas, maka penulis mengangkat PjBL yang inovatif melalui ecoprint yang diharapkan dapat membantu meningkatkan ketrampilan 4C. Pembelajaran dengan ecoprint ini diharapkan dapat menyiapkan generasi menghadapi tantangan global abad 21 dan revolusi 4.0 yang lebih cinta dan peduli terhadap lingkungan.

Maka di sini mengangkat PjBL yang dikaitkan dengan karya dekoratif batik yaitu ecoprint. Peserta didik bisa belajar pada sub tema teknologi sandang secara tematik integratif yaitu matematika, bahasa indonesia, PPKn, dan SBdP. Hal ini akan membuat pembelajaran lebih bermakna.

Sebelum membuat rancangan maka perlu analisis KD dan indikator, Analisis materi tematik, dan analisis ketrampilan 4C. Sebelum membuat desain media pembelajaran perlu analisis indikator pembelajaran tematik yang dilihat dari kompetensi dasar KD, seperti tercantum pada tabel 3.1

Tabel 3.1. Tabel Pemetaan Indikator

\begin{tabular}{|c|c|}
\hline Matematika & Bahasa Indonesia \\
\hline 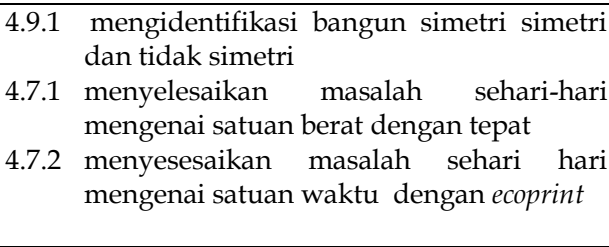 & $\begin{array}{l}\text { 4.6.1 } \begin{array}{c}\text { menuliskan pokok informasi } \\
\text { perkembangan teknologi sandang }\end{array} \\
\text { 4.6.2 } \begin{array}{l}\text { meringkas teknologi produksi dalam } \\
\text { membuat ecoprint }\end{array} \\
\text { 4.1.1 } \begin{array}{l}\text { menuliskan informasi dengan kalimat } \\
\text { efektif. }\end{array} \\
\text { 4.1.2 } \begin{array}{l}\text { menceritakan hasil pengamatannya } \\
\text { mental }\end{array}\end{array}$ \\
\hline Bahasa Indonesia & SDdP \\
\hline $\begin{array}{l}\text { 4.1.1 mengidentifikasi dan menceritakan } \\
\text { pengalaman kegiatan gotong royong } \\
\text { yang telah dilaksanakan saat mebuat } \\
\text { ecorpint ecoprint. } \\
\text { 4.1.2 menyajikan laporan dengan presentasi } \\
\text { makna keberagaman karasteristik } \\
\text { individiu saat membuat ecoprint }\end{array}$ & $\begin{array}{l}\text { 4.1.1 membuat karya dekoratif dengan } \\
\text { ecoprint bertema bangun simetris } \\
\text { dari tumbuhan }\end{array}$ \\
\hline
\end{tabular}

Berdasarkan teori yang diungkap bahwa PjBL ini dapat meningkatkan kecakapan global abad 21 dan mengarah pada ketrampilan 4C (komunikasi, kolaborasi, berpikir kritis, dan kreativitas). Maka dari itu perlu dikembangkan sebuah model PjBL melalui ecoprint untuk meningkatkan ketrampilan 4C. 


\section{Desain Media}

Setelah melakukan analisis kebutuhan media yang dapat dimanfaatkan untuk pembelajaran kelas 4 tema 8, maka penulis mulai merancang media. Dari beberapa aspek kompetensi yang ingin dicapai, penulis memutuskan memanfaatkan media ecoprint. Dengan ini memiliki ide agar ecoprint pada kain ini dapat digunakan untuk pembelajaran yang dikemas secara tematik, seperti matematika dengan mengukur masa, belajar volume; PPkn belajar kerjasama sama dan gotong royong; bahasa indonesia meringkas tentang proses teknologi dan belajar perubahan wujud; SBdP membuat karya dekoratif bangun simetri.

Guru selaku penulis sudah sering membuat karya ecoprint dan sudah menghasilkan beberapa karya yang layak seperti pada gambar 3.1.

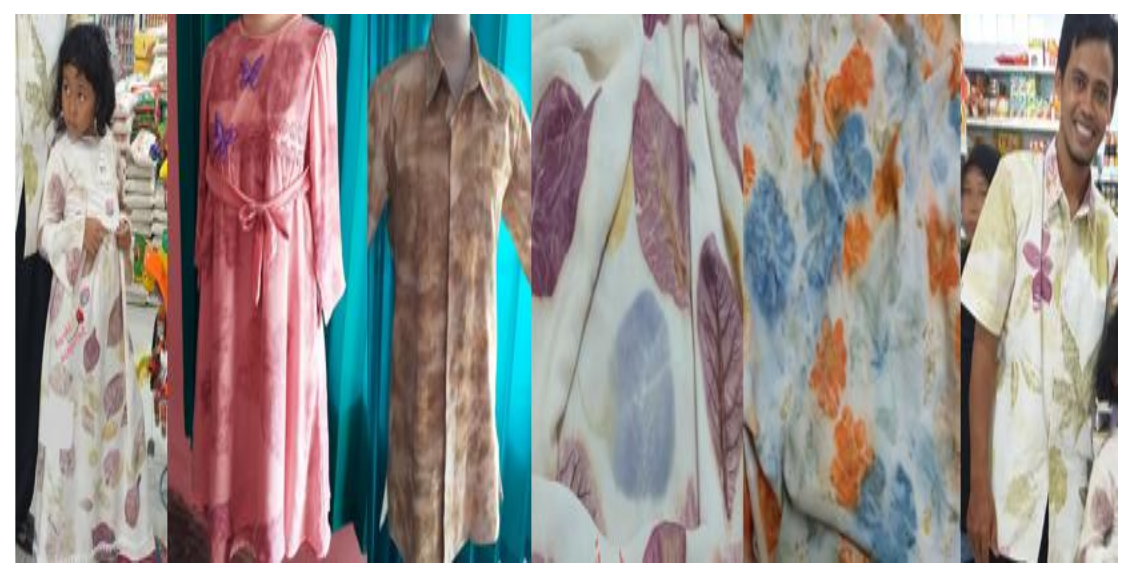

Gambar 3.1. Contoh hasil produk ecoprint yang sudah dibuat penulis

Ecoprint dalam pembuatan ada berbagai cara, namun pada penelitian ini kita menggunakan teknik kukus, karena selain lebih cepat, dan lebih mudah bagi anak dan menghasilkan warna yang lebih tahan lama. Menurut (Maharani, 2018) proses pewarnaan dengan ecoprint dapat diperoleh dengan cara pengukusan untuk menghasilkan cap daun dari bagian tumbuhan ke dalam kain. Proses membuat ecoprint, sebagai berikut: 1) menyiapkan alat dan bahan; 2) merendam kain dengan air tawas; 3) menata pola daun di atas kain; 4) melipat kain agar simetris; 5) menggulung kain dengan tali; 6) mengukus; 7) membuka gulungan; 8) mengunci warna (fiksasi). 
Proyek yang dilaksanakan agar sesuai, maka sebelum pembelajaran penulis membuat prototipe terlebih dahulu. Gambar proses pembuatan karya dekoratif dengan ecoprint dapat terlihat seperti gambar 3.2.

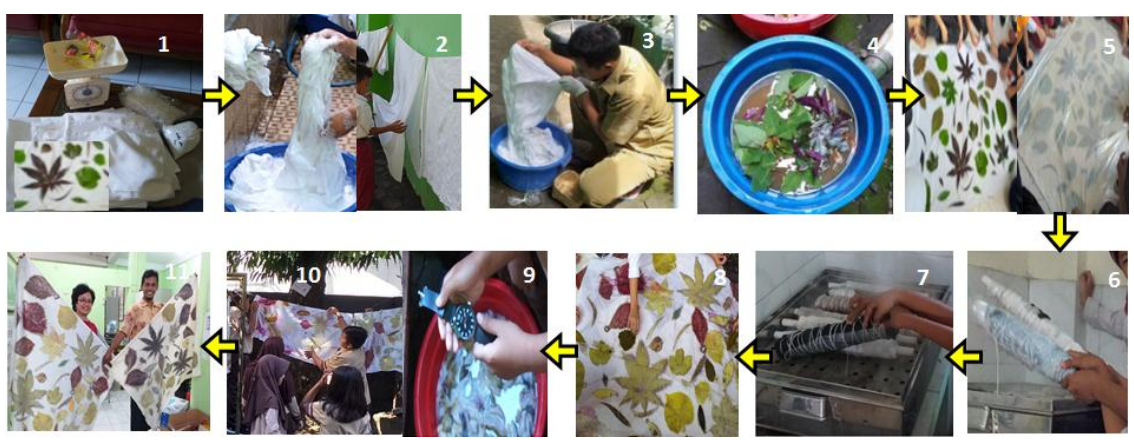

Gambar 3.2. Proses membuat karya dekoratif ecoprint bangun simetris

Dalam membuat karya bangun simetri dengan ecoprint ini tentunya dapat dikaitkan dengan pembelajaran tematik teknologi sandang. Pembelajaran lebih cocok ketika diterapkan dengan PjBL, karena memecahkan sebuah permasalahan dan menghasilkan sebuah produk. Penggunaan teknologi multimedia interaktif dengan power point juga dipilih karena mudah dan menarik. Multimedia dikemas lebih interaktif. Dengan multimedia ini peserta didik dapat berinteraksi dengan mengetikan jawaban, mengukur dengan penggaris, mengisi tabel dan menyimpulkan sendiri jawabanya untuk lebih mengenal simetri.
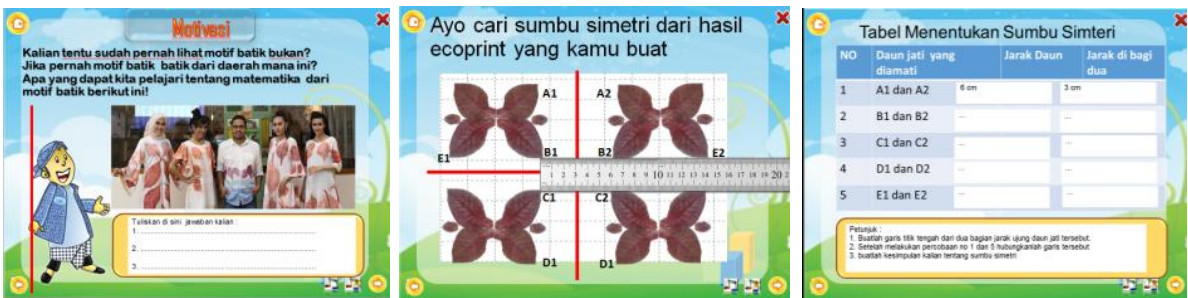

Gambar 3.3 Multimedia interaktif dengan power point

Penilaian yang yang dilakukan oleh peneliti adalah peniliain ketrampilan yang menunjang pembelajaran abad 21 yaitu penilaian ketrampilan $4 \mathrm{C}$. Ketrampilan 4C Dalam membuat ecoprint kreativitas dalam merancang dan hasil produk ecoprint, kerjasama dalam proses membuat ecoprint, 
berpikir kritis dalam pembuatan laporan dan presentasi, dan berkomunikasi saat presentasi.

Desain Rancangan desain awal PjBL melalui Ecoprint tahL dilakukan seperti bagan 3.4 betikut:

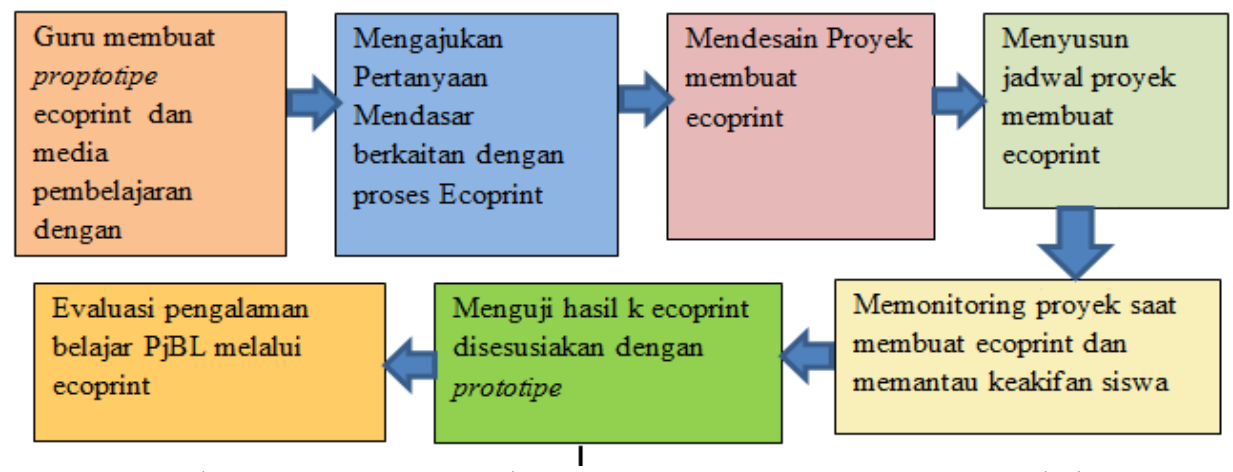

Gambar 3.4 Diagram alur Rancangan Karya Inovasi Pembelajaran

\section{Implementasi Media Pembelajaran}

\section{Uji Coba Kelompok Kecil}

Dalam pembelajaran tematik diambil materi yang berkaitan dengan PPKn materi gotong royong dan menghargai individu; matematika mengukur massa benda; SBdP membuat karya dekoratif; dan bahasa indonesia mengambil informasi berhubungan dengan teknologi sandang. Model PjBL pada kelompok kecil terlihat secara singkat seperti tabel 3.2.

Tabel 3.2 Model PjBL untuk Kelompok Kecil

\begin{tabular}{|c|c|c|}
\hline No & Sintak & Aktivitas guru dan siswa \\
\hline 1 & $\begin{array}{l}\text { Penentuan pertanyaan } \\
\text { mendasar }\end{array}$ & $\begin{array}{l}\text { - Mengajukan } 4 \text { pertanyaan tentang membuat karya dekoratif } \\
\text { pada mapel PPkn, SbDB, Matematika, B.Indonesia }\end{array}$ \\
\hline 2 & $\begin{array}{l}\text { Menyusun } \\
\text { perencanaan proyek }\end{array}$ & $\begin{array}{l}\text { - Peserta didik menyiapkan alat dan bahan dan berdiksui tentang } \\
\text { pertanyaan yang sudah diajukan. } \\
\text { - Guru menyiapkan multimedia bangun simetri dnengan power } \\
\text { point dan video proses pembuatan ecoprint, } \\
\text { - Membuat ecoprint bangun simetris dengan satu kain dan } 2 \text { kain }\end{array}$ \\
\hline 3 & $\begin{array}{lr}\text { Menyusun } & \text { jadwal } \\
\text { proyek } & \text { membuat } \\
\text { Ecoprint } & \end{array}$ & $\begin{array}{l}\text { - Guru dan siswa membuat kesepakatan bersama hari dan } \\
\text { tanggalnya. } \\
\text { - Peserta didik melakukan pembelajaran di luar waktu sekolah } \\
\text { juga }\end{array}$ \\
\hline 4 & $\begin{array}{l}\text { Monitoring pelaksanaan } \\
\text { proyek }\end{array}$ & $\begin{array}{l}\text { - Guru mengamati dan memnitorng siswa mengerjakan proyek } \\
\text { sambil mengadakan observasi }\end{array}$ \\
\hline 5 & $\begin{array}{l}\text { Menguji hasil dari } \\
\text { produk yang dihasilkan }\end{array}$ & $\begin{array}{l}\text { - Menguji hasil proyek ecoprint } \\
\text { - Uji performan saat presentasi peserta didik }\end{array}$ \\
\hline 6 & $\begin{array}{l}\text { Evaluasi pengalaman } \\
\text { Belajar }\end{array}$ & $\begin{array}{l}\text { - Evaluasi dilaksankan oleh guru dan dan peseta didik lain setelah } \\
\text { anak melakukan presentasi. }\end{array}$ \\
\hline
\end{tabular}


Pelaksanaan proyek ini menggunakan power point untuk memudahkan belajar tentang bangun simetri. Setelah itu peserta didik mencoba untuk mambuat ecoprint. Selama membuat ecoprint ini guru memonitoring dengan bertanya kepada kelompok tentang tugas proyek dari pertanyaan mendasar tersebut. Untuk menguji maka selama pembelajaran dilaksanakan penilaian autentik ketrampilan kolaborasi, komunikasi, berpikir kritis, dan kreativitas. Kriteria penilaian di mulai dari mendesain ecorpint, membuat ecoprint, produk ecoprint, dan presentasi ecoprint. Gambar hasil dari uji coba kelompok kecil dapat ditampilkan dalam gambar 3.5.
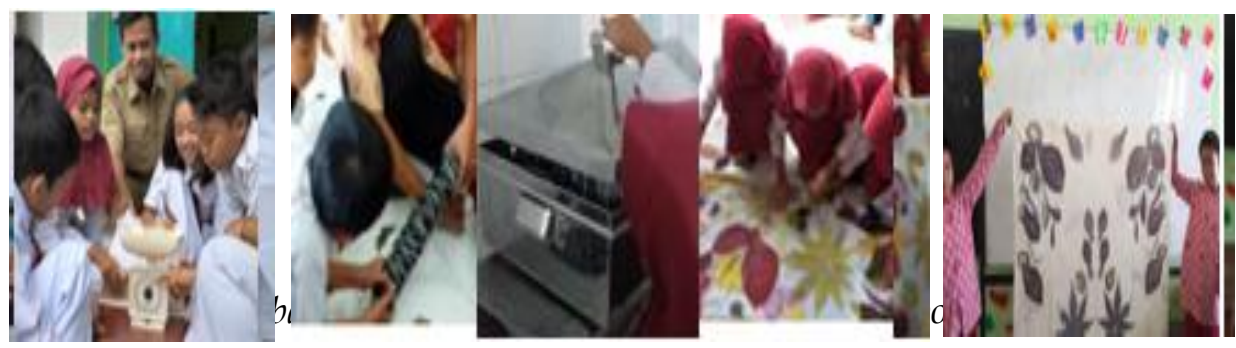

\section{Uji Coba Kelompok Besar}

Berdasarkan uji coba kelompok kecil maka guru berdiskusi dengan validator dan pembelajaran diperbaiki kembali model II secara sekilas terlihat dalam tabel 3.3.

Tabel 3.3. Model PjBL pada kelompok Besar

\begin{tabular}{|c|c|c|}
\hline No & Sintak & Aktivitas guru dan siswa \\
\hline 1 & $\begin{array}{l}\text { Penentuan pertanyaan } \\
\text { mendasar }\end{array}$ & $\begin{array}{l}\text { Pertanyaan dengan kajian yang berbeda yang terdiri dari diberi } 8 \\
\text { pertanyan tentang matematika, Bahasa Indonesia ada materi IPA dan } \\
\text { teknologi, PPPKn. }\end{array}$ \\
\hline 2 & $\begin{array}{l}\text { Menyusun perencanaan } \\
\text { proyek }\end{array}$ & $\begin{array}{l}\text { Perencanaan } 8 \text { kelompok dengan } 8 \text { pertanyaan tematik IPA, Bahasa } \\
\text { Indonesia, SbdB, PPkn, Matematika } \\
\text { Guru menyiapkan bahan teks bacaan teknologi membuat ecoprint } \\
\text { dan cinta lingkungan dengan ecoprint. } \\
\text { Guru mengedit multimedia pembelajaran dan menambah geogbra }\end{array}$ \\
\hline 3 & $\begin{array}{l}\text { menyusun jadwal } \\
\text { proyek }\end{array}$ & $\begin{array}{l}\text { Memahami lebih lanjut tentang ecoprint dan simetri dengan } \\
\text { multimedia Interaktif } \\
\text { Mempelajari perbedaan volum, mengukur waktu saat menrendan } \\
\text { kain dengan cairan panas dan tawas (Matematika) } \\
\text { Mengamati proses perubahan wujud saat mencairkan tawas, } \\
\text { menjemur pakain (IPA) } \\
\text { Membuat karya dekoratiif bangun simetris pada kain (SbDB dan } \\
\text { matematika) } \\
\text { Menuliskan nilai gotong royong dan kerjasama (Pkn) } \\
\text { Mempelajari teknologi membuat karya dekoratif dan teknologi } \\
\text { sandang dalam membuat kain ecoprint (Bahasa Indonesia) }\end{array}$ \\
\hline
\end{tabular}




\begin{tabular}{|c|c|c|}
\hline No & Sintak & Aktivitas guru dan siswa \\
\hline & & $\begin{array}{l}\text { - mendiskusikan hasil produk } \\
\text { melakukan gerakan cinta lingkungan dengan menanam tanaman } \\
\text { yang bisa di ecoprint }\end{array}$ \\
\hline 4 & $\begin{array}{l}\text { Monitoring } \\
\text { pelaksanaan proyek }\end{array}$ & $\begin{array}{l}\text { memastikan anak melaksanakan tugas } \\
\text { mengecek lks yang sudah dikerjakan } \\
\text { o mengecek tangung jawabanya dengan mengecek laporan } \\
\text { merekam video saat melaksanakan proyek } \\
\text { menilai ketampilan }\end{array}$ \\
\hline 5 & $\begin{array}{l}\text { Menguji hasil dari } \\
\text { produk yang } \\
\text { dihasilkan }\end{array}$ & $\begin{array}{l}\text { menguji kelayakan produk } \\
\text { mempresentasikan hasil karyanya di depan } \\
\text { berdiskusi tentang kelebihan dan kekurangan } \\
\text { menilai ketrampilan }\end{array}$ \\
\hline 6 & $\begin{array}{l}\text { Evaluasi pengalaman } \\
\text { belajar }\end{array}$ & $\begin{array}{l}\text { evaluasi dilakukan dengan melihat hasil video dan foto saat } \\
\text { melaksanakan proyek. } \\
\text { mengevaluasi dari rekan sejawat dan orang tua tentang proyek yang } \\
\text { sudah dilaukan }\end{array}$ \\
\hline
\end{tabular}

Proyek PjBL di mulai dengan pertanyaan mendasar, peserta didik diberi pertanyaan awal. Selanjutnya dibagi 8 kelompok berbeda untuk memecahkan sebuah permasalahan yang terdiri dari Matematika, Bahasa Indonesia yang ada muatan IPA, PPPKn dan SBdP. Selain itu juga monitoring terhadap penilaian $4 \mathrm{C}$ dilakukan selama proyek pembelajaran berlangsung. Penilaian antar teman dilakukan agar peserta didik lebih semangat dalam mengerjakan tugasnya.
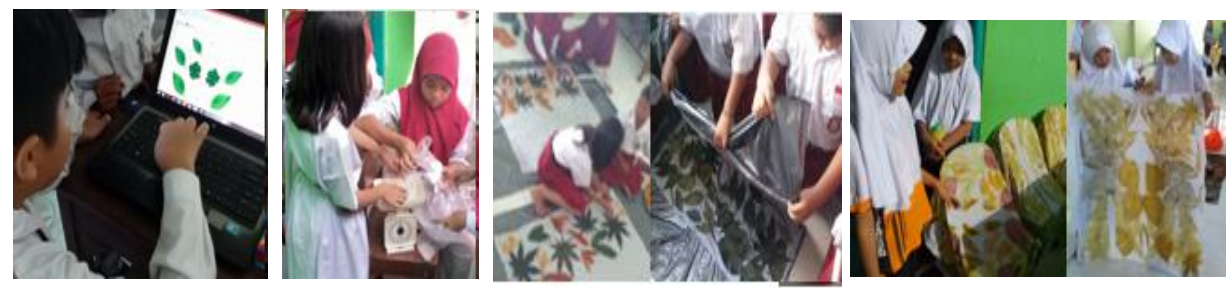

Gambar 3.6 Implemnetasi Model PjBL Kelompok Besar

Uji performan dilakukan saat mereka mempresentasikan hasil karya mereka. Uji performan dan evaluasi kelebihan dan keurangan produk sesuai dengan proptotipe secara acak dilakukan dengan mengetahui bangun simetri Peserta didik juga memamerkan karya di luar kelas, mereka saling berkunjung untuk menguji produk dan presesntasi laporan. Presentasi dilakukan ada dua cara ada yang menggunakan kertas 
plano ada yang menggunakan power point. Gambar pelaksananya seperti terlihat dalam gambar 3.6.

\section{Data Hasil Aplikasi Praktis Inovasi Pembelajaran}

Dari validasi model yang dilakukan validator juga memberikan masukan untuk perbaikan model yang telah dibuat. Berikut adalah rangkuman masukan yang dapat dilihat pada tabel 3.4

Tabel 3.4. Masukkan validasi pra uji

\begin{tabular}{|c|l|l|}
\hline No & \multicolumn{1}{|c|}{ Kriteria } & \multicolumn{1}{c|}{ Masukkan } \\
\hline 1 & Penentuan pertanyaan mendasar & $\begin{array}{l}\text { Perlu di tambah materi-materi yang } \\
\text { terintegrasi lain agar lebih bermakna }\end{array}$ \\
\hline 2 & Menyusun perencanaan proyek & $\begin{array}{l}\text { Perencanaan membuat bangun simetris } \\
\text { ecoprint dilakukan dengan 1 dan 2 kain }\end{array}$ \\
\hline 3 & Menyusun jadwal proyek & Jadwal proyek tidak terlalau lama \\
\hline 4 & Monitoring pelaksanaan proyek & Monitoring dapat di lihat dari LKPD \\
\hline 5 & Menguji hasil dari produk yang dihasilkan & $\begin{array}{l}\text { Dalam menguji di beri pertanyaan yang } \\
\text { menuju arah berpikir kritis }\end{array}$ \\
\hline 6 & Evaluasi pengalaman & $\begin{array}{l}\text { Perlu dievaluasi kesesuain produk } \\
\text { dengan hasil yang diharapakn }\end{array}$ \\
\hline
\end{tabular}

Tabel 3.5. Masukan dari hasil uji coba kelompok kecil

\begin{tabular}{|c|l|l|l|}
\hline No & \multicolumn{1}{|c|}{ Kriteria } & \multicolumn{3}{|c|}{ Masukkan } \\
\hline 1 & Penentuan pertanyaan mendasar & $\begin{array}{l}\text { Perlu di buat pertanyaan yang sudah tersusun } \\
\text { menjadi 8 kelompok yang berbeda }\end{array}$ \\
\hline 2 & Menyusun perencanaan proyek & $\begin{array}{l}\text { - Membuat teks wacana berhubungan cinta } \\
\text { lingkungan dengan ecoprint } \\
\text { - Perlu tambahan geogebra untuk memepelajrai } \\
\text { simetri }\end{array}$ \\
\hline 3 & Menyusun jadwal proyek & Ada gerakan cinta lingkungan menanam & \\
\hline 4 & Monitoring pelaksanaan & Perlu penilaian antar teman & \\
\hline 5 & Menguji hasil produk & $\begin{array}{l}\text { Perlu sebuah pameran untuk lebih menarik } \\
\text { perhatian }\end{array}$ \\
\hline 6 & Evaluasi pengalaman & Saat evaluasi memutar video rekaman pembelajaran \\
\hline
\end{tabular}

\section{Tabel 3.6. Masukkan Hasil dari Uji lapangan}

\begin{tabular}{|c|l|l|}
\hline No & \multicolumn{1}{|c|}{ Kriteria } & \multicolumn{1}{|c|}{ Masukan } \\
\hline 1 & Penentuan pertanyaan mendasar & $\begin{array}{l}\text { Pertanyaan mendasar pada permasalahan yang } \\
\text { menuntut studi kasus yang harus dipecahkan } \\
\text { bersama. }\end{array}$ \\
\hline 2 & Menyusun perencanaan proyek & Perlu pembagian kelompok yang lebih hiterogen \\
\hline 3 & Menyusun jadwal proyek & $\begin{array}{l}\text { Perlu ditambahkan jadwal uji coba produk yang } \\
\text { melibatkan orang tua misalnya ikut menonton } \\
\text { pameran dan presentasi anak }\end{array}$ \\
\hline 4 & Monitoring pelaksanaan proyek & $\begin{array}{l}\text { Perlu keterlibatan orangtua agar pembelajaran lebih } \\
\text { bermakna }\end{array}$ \\
\hline 5 & $\begin{array}{l}\text { Menguji hasil dari produk yang } \\
\text { dihasilkan }\end{array}$ & $\begin{array}{l}\text { Produk ecoprint dan di pentaskan misalnya seperti } \\
\text { fashion show }\end{array}$ \\
\hline
\end{tabular}




\begin{tabular}{|c|c|c|}
\hline No & Kriteria & \multicolumn{1}{c|}{ Masukan } \\
\hline 6 & Evaluasi pengalaman Belajar & $\begin{array}{c}\text { Perlu presentasi pembelajaran oleh anak untuk } \\
\text { meningkatkan kemampuan komuniksi } \\
\text { - Menggunkan daun bekas ecoprint untuk pupuk }\end{array}$ \\
\hline
\end{tabular}

Peserta didik diberikan angket yang terdiri dari 22 pertanyaan yang dibagi menjadi aspek PjBL yang terdiri dari 10 pertanyaan, dan kemampuan kolaborasi 4 pertanyaan, berpikir kritis 3 pertanyaan, ketrampilan komunikasi 3 pertanyaan dan ketrampilan krativitas 2 pertanyaan. Angket ini digunakan sebagai alat untuk klarifikasi sesuai degan data yang diperoleh, selain untuk menganalisis hasil praktis inovasi pembelajaran.

\section{Analisis Hasil Aplikasi Praktis Inovasi Pembelajaran}

Dari data yang diperoleh dari uji coba kelompok kecil, dan ujicoba lapangan pada tabel 7 di atas, maka dapat di buat tabel 3.7. dan grafik pada gambar 3.8. Sehingga bisa terlihat gambarannya.

Tabel 3.7. Hasil Uji Validasi Model PjBl

\begin{tabular}{|c|c|c|c|}
\hline Pengamat & Kelompok kecil & Kelompok besar & Skor Ideal \\
\hline P1 & 79 & 84 & 100 \\
\hline P2 & 81 & 85 & 100 \\
\hline Rata_Rata & 80 & 84,5 & 100 \\
\hline
\end{tabular}

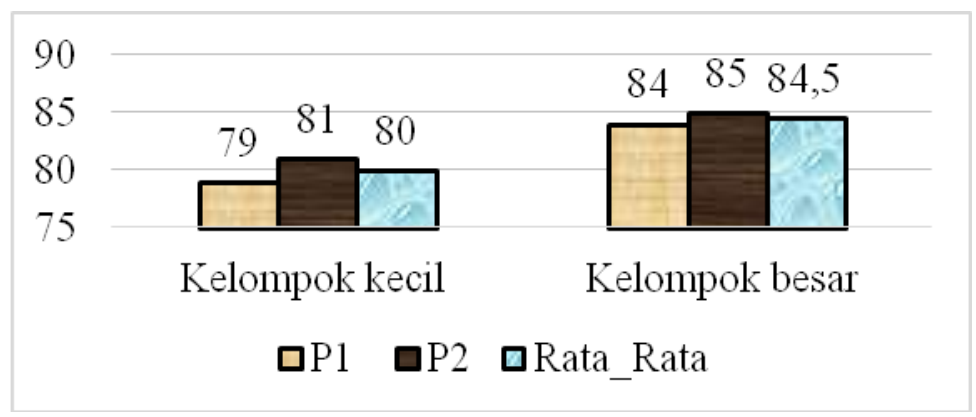

Gambar 3.8. Grafik Uji coba PjBL Melalui Ecoprint

Dari grafik 2.8 memperlihatkan adanya peningkatan hasil validasi dari validator dengan kualifikasi sangat baik. Hal ini dapat digunakan sebagai indikasi bahwa model PjBL ini dapat di gunakan dengan berbagai masukkan.

Dari tabel 2.5 terlihat masukkan dari validator tentang gambaran model yang harus diperbaiki. Terlihat bahwa pada pra model terlihat 
perlu perubahan membuat pertanyaan yang lebih rinci dari 8 kelompok dengan pertanyaan yang mengarah kepada ketrampilan berpikir kritis. Pertanyaan tersebut terdiri dari 3 permasalahan matematika, 2 pertanyaan PPPKn, 2 pertanyaan bahasa indonesia, dan 1 permasalahan SBdP. Untuk bahasa Indonesia adalah kelompok 1 menjelasakan peristiwa IPA apa yang terjadi saat membuat ecorprint dan kelompok 2 yaitu menuliskan langkahlangkah yang harus dilakukan saat membuat ecoprint. Untuk PPKn adalah kelompok 3 menjelaskan dan menganalisis kerjasama dalam membuat ecoprint dan kelompok 4 menganalisis hak dan kewajiban apa saat membuat ecoprint. Matematika adalah kelompok 5 menyelsaikan masalah menimbang dan mengukur kebutuhan tawas yang yang dikaitkan dengan jumlah bahan 8 meter, kelompok 6 menyelesaiakn masalah berkaitan dengan volume air yang dibutuhkan untuk merendam kain sebelum di ecorprint dan Kelompok 7 menyelesaiakn maslaah mencatat waktu yang dibutuhkan saat membuat ecoprint. SbDB terntegrasi matematika adalah kelompok 8 mempersipakan langkah membuat karya dekoratif bangun simetris.

Pelaksanaan proyek pembuatan ecoprint karya dekoratif bangun simetri ada dua cara dengan teknik satu kain yang ditata daun di separuh kain selanjutnya dilipat sehingga bisa membentuk dua buah bangun simetri pada kain yang sama. Monitoring pelaksanaan proyek dapat dilihat dari LKS yang sudah dilakukan, dengan bertanya tentang peningkatan secara langsung dari kelompok, dan penilaian antar teman.

Ujicoba dilakukan dengan cara membandingkan dengan prototipe yang sudah disediakan sebelumnya, selanjutnya mengevaluasi terhadap konsep materi membuat karya dekoratif bangun simetri dan dikaitkan dengan materi yang lainnya. Selain di depan kelas perlu ujicoba dengan memamerkan diluar kelas agar dilihat oleh anak didik atau guru lain. Setelah itu dilakukan peserta diidk membuat laporan untuk menjadi pertanggungjawaban dalam menyelesaikan pertanyaan mendasar. Presentasi hasil oleh peserta didik, dengan melibatkan semua peserta didik ikut serta mengambil bagian dalam presentasi. Selain itu untuk meningkatkan kemampauan berpikir kritis guru memberikan pertanyaan yang mengarah 
berpikir kritis. Penilaian autentik untuk megetahui kemampuan berpikir kritis, dan konumikasinya juga diamati dalam proses ini.

Evaluasi pengalaman dengan cara berdiskusi proses pembuatan ecoprint dengan memutar video rekaman pembelajaran yang dilakukan untuk meningkat kemampuan komunikasinya. Pameran karya juga diadakan dalam bentuk hasil pengolahan ecoprint misalnya fashion show di depan guru, anak didiklain bahkan masyarakat stake holder. Presentasi tentang pembelajaran dilakukan juga untuk menambah kemampuan komunikasi yang sudah dilakukan oleh siswa saat pentas seni dengan ecoprint tersebut.

Penggunaan teknologi pada uji kelompok kecil hanya menggunakan power point ternyata masih kurang presisi, maka pada ujicoba lapangan ditambakan penggunaan GeoGebra karena lebih presisi dalam menentukan sumbu simetri dan mendesain ecoprint lebih menarik. Penggunaan multimedia interaktif power point juga ditambahkan tempat tex box kosong untuk mengisi materi saat anak presentasi. Pengunaan teknologi multimedia dengan power point dan GeoGebra seperti gambar 3.9 a dan $3.9 \mathrm{~b}$, kelebihanya selain mudah, interaktif juga sifatnya offline. Penggunaan tekologi ini, jika presentasi dengan multimedia tidak memungkinkan maka bisa secara manual misalnya menggunakan kertas plano. Begitu juga untuk GeoGebra jika tidak memungkikan bisa menggunakan kertas gambar berpetak untuk menentukan sumbu simetrinya.
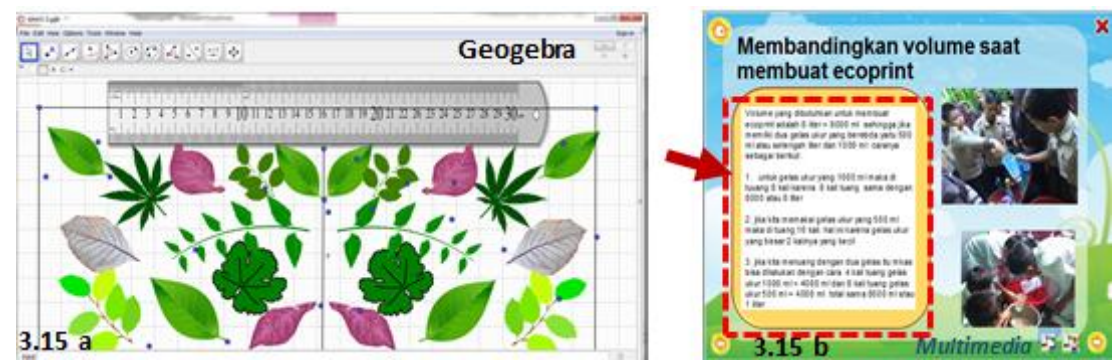

Gambar 3.9 a Penggunaan teknologi GeoGebra

Gambar 3.9 b Penggunaan teknologi multimeida interaktif

Selama proses pembelajaran guru mengamati peserta didik, dilihat dari kemampuan merancang dan produk yang dinilai adalah kreativitasnya, proses pembuatan dinilai kerjasamanya, pembuatan laporan yang dinilai berpikir 
kritis, dan kemampuan presentasi dinilai berpikir kritis dan komunikasinya. Penilain berdasarkan kisi-kisi tabel 2.3 tentang ketrampilan berpikir kritis. Analisis hasil ketrampilan bisa dilihat di lampiran 14. Selain itu peneliti juga menkroscek dengan cara melihat hasil dari angket dan masukkan penilaian antar teman. Hasil penilaian ketrampilan $4 \mathrm{C}$ dari kelompok kecil dan kelompok besar terlihat pada tabel 3.8 dan grafik 3.9-3.10.

Tabel 3.8. Hasil Penilaian Ketrampilan 4C 2 kelompok

\begin{tabular}{|c|c|c|c|c|c|c|}
\hline Ujicoba & Kreativitas & Kerjaasma & $\begin{array}{c}\text { Berpikir } \\
\text { kritis }\end{array}$ & Komunikasi & $\begin{array}{c}\text { Skor } \\
\text { Total }\end{array}$ & Nilai \\
\hline Kelompok kecil & 3 & 3,5 & 2,8 & 3 & 12,3 & 76,6 \\
\hline Kelompok besar & 3,5 & 3,8 & 3,2 & 3,1 & 13,6 & 84,8 \\
\hline
\end{tabular}

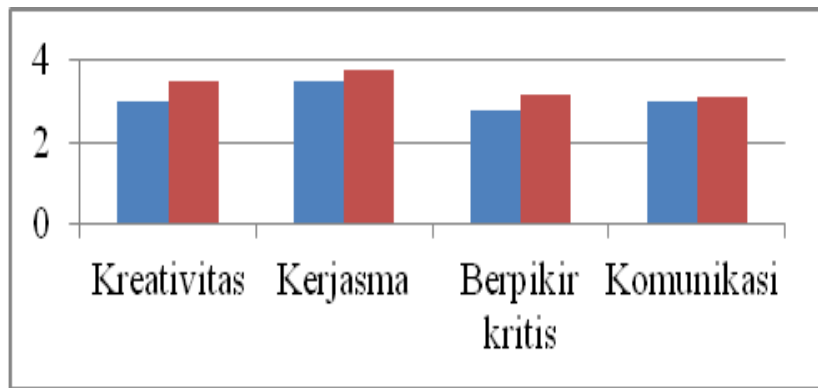

Ujicoba

kelompok kecil

Ujicoba

kelompok besar

Gambar 3.9. Grafik peningkatkan ketrampilan 4C pada saat ujicoba

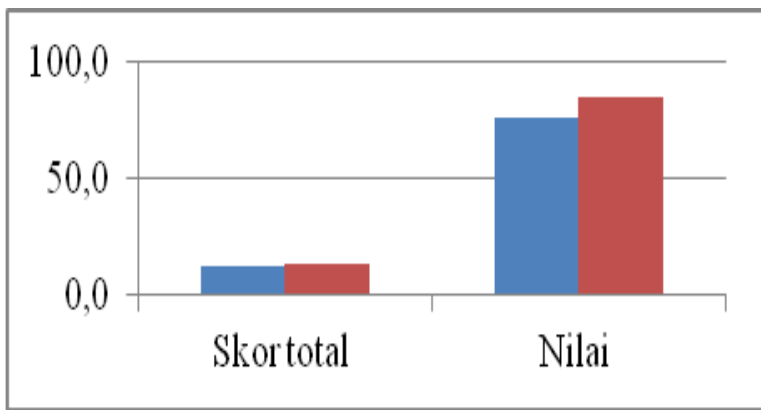

Ujicoba

kelompok kecil

Gambar 3.10. Grafik peningakatkan skor dan nilai 4C

Dari tabel 3.9 dan grafik 3.10 terlihat pada setiap aspek ketrampilan 4C pada prosesnya mulai dari kreativitas saat merancang dan produk ecoprint, kerjasama saat membuat ecoprint, berpikir kritis saat presentasi dan membuat laporan, dan berkomunikasi saat presentasi mengalami 
peningkatan. Nilai akhir pada saat penilain setiap kelompok dapat menuntaskan proyek dari KKM 80, sesuai dengan nilai yang sudah ditentukan sebelumnya. Dapat terlihat juga peningkatan hasil akshir dari uji kelompok kecil dengan nilai 76,6 menjadi 84,8 pada ujicoba kelompok besar. Sehingga dapat dikatakan bahwa PjBL ini dapat meningkatkan ketrampilan 4C.

Peningkatan keterampilan, selain dilihat dari presentasi sebelum diadakan pembelajaran proyek dan sesudah proyek dilakukan. Juga dilihat dari pengamatan saat pelaksanaan proyek dilakukan. Kemampaun $4 \mathrm{C}$ dapat diuraikan sebagai berikut ini:

1) Kemampuan berpikir kritis peserta didik meningkat saat dilihat dari antusiasne untuk menjawab pertanyaan tinngkat tinggi dari peserta dan guru. Contoh pada kelompok membandingkan volume, "Jika dalam membuat ecoprint dibutuhkan 8 liter. Jika pada gelas ukur besar dituang dua kali. Berapa kali tuang kekurangan yang harus di lakukan untuk nenambah pada gelas ukur yang kecil?" Peserta didik bisa menjawab pertanyaan ini sekaligus dengan penjelasannya. Hal tersebut menunjukkan bahwa anak sudah peningkatan ketrampilan berpikir kritisnya dengan mengidentifikasi, dan menyelsaikan masalah sesuai konsep, membuat keputusan dengan tepat.

2) Kemampuan komunikasi peserta didik terlihat banyak bertanya ketika mereka mengalami kesulitan, sehingga muncul ide ide gagasan baru dari peserta lain untuk menyelesaikan. Saat presentasi setiap kelompok berusaha menjawab pertanyaan dari teman dan guru dan semuanya menyelesaikan laporan tertulis. Hal ini nampak dari video saat mereka presentasi.

3) Kemampuan kolaborasi sangat terlihat pada saat mereka bekerja membuat ecoprint dengan dilihat dari penilaian antar teman sebaya mereka semua saling bekerja sama, dan antusias menyelesaikan tugas yang menjadi tanggung jawabnya. Ketika ada kelompok ain belum selesai atau tidak dapat mengikat dan menggulung kelompok lain saling membantu jadi ada rasa empati.

4) Kreativitas anak dapat dilihat dari hasil desain dan produk yang di tampilkan dari ecoprint karya anak sudah menggunakan konsep yang benar yaitu konsep bangun simetris. Selain itu mereka memliki ide baru yang dapat menambah kualitas karya dengan penataan daunnya. 
Dalam kaitannya dengan angket yang diberikan terlihat dalam lampiran 8, dan dianalisis di lampiran 15 dari pertanyan nomor 11-22 tentang ketrampilan $4 \mathrm{C}$ semuannya capaian presentasinya di atas $80 \%$. Bahkan ada yang 5 butir pertanyaan ada yang mencapai lebih dari $90 \%$. Hal ini menunjukkan kesesuaian dengan pengamatan dan hasil yang diperoleh. Dilihat juga dari komentar peserta didik ada yang bertambah komunikasinya, lebih percaya diri saat bekomunikasi dan lainya.

Dalam PjBL melalui ecoprint ini juga mengajarkan pembelajaran Bahasa Indonesia yang terintegrasi sains, matematika, teknologi GeoGebra dan multimedia. Hal ini sanagt berkaitan antara literasi teknologi dan dan literasi sains. Peserta didik yang memiliki kemampuan sains akan dapat lebih berkomunikasi dengan bahasa yang lebih baik. Hal ini senada dengan Anna Permanasari (2016:27) mengatkan bahwa literasi sains, bahasa dan matematika menunjukan hubungan sangat kuat dan sistemik seseorang yang memiliki literasi teknologi akan lebih berpikir kritis dalam mecahkan masalah dengan literasi bahasa. Orang yang memilki literasi sains akan menggunakan komunikasi dan bahasa simbolik. Selain itu penggunaan GeoGebra juga memancing berpikir kreatif siswa seperti pendapat Atikasari (2015:1) yang mengatakan bahwa pembelajaran menggunakan GeoGebra dapat meningkatkan kemampuan berpikir kreatif siswa.

Pembelajaran pada kurikulum 2013 dikenal dengan pembelajaran tematik integratif, yang cocok untuk diintegrasikan dengan pembelajaran proyek. PjBl ini memeliki keliebihan. Seperti diungkap oleh Anna Permanasari (2016:30) guru besar UPI mengatakan bahwa PjBL merupakan salah satu pembelajaran alternatif yang berpotensi untuk membangun keterampilan abad 21 dan mendekatkan lembaga pendidikan dengan industri. Pembelajaran kooperatif ini dapat meningatkan skill, literasi sains, meningkatkan kreativitas dan pemecahaan masalah.

Dalam penelitian yang sejalan dengan Insyasiska (2019:1) yang mengatakan bahwa $P j B L$ dapat meningkatkan minat belajar siswa, kreativitas siswa, kemampuan berpikir kritis dan kemampuan kognitif sebesar. Pembelajaran berbasis proyek dapat membuat siswa termotivasi untuk belajar menemukan 
informasi dari sumber terpercaya. Siswa juga berkolaborasi dengan tim untuk menghasilkan ide kreatif yang diwujudkan dalam suatu produk. Pembelajaran proyek dapat melatih peserta didik berpikir kritis terhadap permasalahan kontekstual, sehingga dapat meningkatkan kemampuan kognitif peserta didik dengan menganalisis, mensintesis, mengevaluasi, dan mencipta.

\section{Evaluasi}

Setelah dilakukan implementasi di kelas, menunjukkan bahwa media ecoprint berbasis batik ini cukup efektif untuk pembelajarn di SD kelas 4 tema 8 untuk meningkatkan kompetensi 4C siswa. Hal ini terjadi karena batik merupakan benda yang sangat akrab di kehidupan sehari-hari siswa yang tinggal di Kota Yogyakarta sebagai kota batik. Oleh karena itu media ini merupakan media yang berbasis kehidupan siswa dan mengangkat budaya lokal dan sangat memperhatikan kearifan lokal. Dalam membuat pola perlu ada motif-motif lain yang diusulkan oleh siswa, sehingga siswa berpikir kritis, mampu mengkreasi model yang berbeda, dikerjakan secara bersama-sama, dan dikomunikasikan di depan kelas.

\section{Penutup}

\section{Kesimpulan}

1. Model PjBL melalui ecoprint yang dapat meningkatkan ketrampilan 4C pada saat ujicoba kelompok kecil memiliki skor 80 dengan kategori kualitas baik, dan kelompok ujicoba kelompok besar memiliki skor 84,5 dengan kategori sangat baik, sehinngga layak untuk didesiminasikan.

2. Pengembangan model PjBL melalui ecoprint dapat meningkatkan kemampuan 4C (komunikasi, kolaborasi, kerjasama dan berpikir kritis).

\section{Saran}

1. Pembelajaran berbasis proyek diarahkan pada proyek penelitian kaintanya dengan proses pembuatan ecoprint. Misalnya meneliti tentang pengaruh waktu terhadap kekuatan menmpelnya daun.

2. Sekolah perlu memfasilitasi dan mendorong anak menggunakan seragam batik/ecoprint yang menggunakan pewarna alam. 


\section{Ucapan Terimakasih}

Terima kasih Kami sampaikan kepada Ibu Anastasia Sulastri selaku kepala sekolah SDN Petinggen yang telah memberikan ijinnya untuk penelitian ini. Ibu Validator serta rekan guru SDN Petinggen yang telah memberikan semangat dan motivasinya untuk menyelesaikan penelitian ini. Serta anak didikku SDN petinggen yang luar biasa telah berusaha menjadi yang terbaik untuk belajar berkomunikasi, berkolaborasi, berpikir kritis, berkreasi melalui ecoprint ini sehingga dapat menambah motivasi peneliti untuk berinovasi kembali pada materi yang lainnya. Begitu juga kami ucapkan terimakassih kepada orang tua dan komite wali siswa yang ikut menjadi sponsor untuk penelitian ini.

\section{Daftar Referensi}

Ariyana, Y., Bestary, R., Zamroni, Z., \& Pudjiastuti, A. 2018. Buku Pegangan Pembelajaran Berorientasi pada Keterampilan Berpikir Tingkat Tinggi. Jakarta: Dirjen GTK Kemendikbud

Atikasari, G., Kurniasih, A. W. 2015. “Keefektifan Model Pembelajaran Kooperatif Dengan Strategi Ttw Berbantuan Geogebra Terhadap Kemampuan Berpikir Kreatif Matematis Siswa Kelas VII Materi Segitiga". Unnes Journal of Mathematics Education., 4(1)

Insyasiska, D., Zubaidah, S., \& Susilo, H. 2015. “Pengaruh Project Based Learning Terhadap Motivasi Belajar, Kreativitas, Kemampuan Berpikir Kritis, Dan Kemampuan Kognitif Siswa Pada Pembelajaran Biologi". Jurnal Pendidikan Biologi, 7(1), 9-21

Maharani, A. 2018. "Motif dan Pewarnaan Tekstil di Home Industri Kaine Art Fabric Ecoprint Natural Dye." Journal.student.uny.ac.id, 7(4), 383-394

Nurhayati, A. S. 2018. Penerapan Bembelajaran Abad 21 Memanfaatkan Rumah Belajar. Jakarta : PusTekom Kementrian Pendidikan dan Kebudayaan

Permanasari, A. 2016. STEM Education: Inovasi dalam Pembelajaran Sains. Prosiding Seminar Nasional Pendidikan Sains Peningkatan Kualitas Pembelajaran Sains dan Kompetensi Guru Melalui Penelitian \& Pengembangan dalam Menghadapi Tantangan Abad-21 USM: Surakarta, 22 Oktober 2016.23-24 